\title{
Sinemada Hatırlamanın Politikası: Gece ve Sis*
}

\author{
Ar. Gör. PInar YILDIZ
}

ankara üniversitesi iletişim fakültesi radyo televizyon ve sinema bölümü hicranada@gmail.com

\section{Abstract \\ The Politics of Remembering in Cinema: Night and Fog}

Tracing the problems of representing the Holocoust or alike traumas, in other words, endeavoring to translate the traumas into the cinema language enables us to discuss the ethical-political dimension of reminding the past on the cinema screen. Alain Resnais' movie Night and Fog (1955) positions in the intersection of trauma studies and film studies. The movie has been in the center of discussions on representation because of its narrative, using the real images of genocide directly while merging black and white archive images of Auschwitz and Birkenau concentration camps and contemporary colored images. The form of the movie is composed by the moments of collapse of the narrative, silences, gaps and encounters in which the traditional narrative form fails to represent. However, it is not adequate to explain Night and Fog's significance in the cinema history only by its formal choices. The ethical position which this formal choices locate us as audiences is the main reason of this movie's privileged status in regard to the representability of trauma in cinema. The relation of the movie with the past through its form creates an ethical realm by calling the audience to take responsibility for what he/she sees on the screen. Therefore, Night and Fog bears its status as the reference point of "representational ethics" in the history of cinema.

keywords: film studies, trauma studies, memory, representation, post-traumatic cinema

\footnotetext{
* Makalenin ilk halini okuyan ve önerileriyle katkıda bulunan Umut Tümay Arslan'a teşekkür ederim.
} 


\section{Résume}

\section{Politique de mémoire au cinéma: Nuit et Brouillard}

Aborder les problèmes de la représentation de traumatism dans le langage cinématographique (Holocaust ou autres) nous permet de discuter sur les liens entre mémoire et éthique-politique au cinéma. Le film de Nuit et Brouillard I Night and Fog, 1955) d'Alain Resnais se trouve à cette croisée, entre études sur les traumatismes et études de films. Cette oeuvre associe archives en noir et blanc d'Auschwitz et Birkenau et images tournées en couleur. L'utilisation des images directes relatives au génocide l'a placé au centre d'une controverse. Le structure formel de film se base sur les moments où le récit chute, le silence, le vide ainsi que les rencontres où le récit traditionnel échoue. Pourtant, ce choix formel n'est pas suffisant pour expliquer sa grande importance dans l'histoire du cinéma. Le succes du film vient du positionnement éthique loù sont emmenés les spectateurs) caractérisé par le choix formel qui ouvre les débats sur la représentation de traumatisme. En faisant, par les procédés formels utilisés, une connexion avec le passé, le film pose une question éthique afin de sensibiliser ses spectateurs autour de tout ce que l'on voit sur l'écran. Ainsi le film ouvre une voie aux débats sur "I'éthique de la représentation" en obtenant une place de référence dans I'historique du cinéma

mots-clés: les études filmiques, les études de trauvmatisme, mémoire, représentation, cinéma post-traumatique

\section{Özet}

Holokost ve benzeri travmaları temsil etmenin bir diğer deyişle travmayı sinema diline tercüme etmeye çalışmanın karşı karşıya kaldığı soru(n)ların peşinden gitmek, sinema perdesinde geçmişi hatırla(t)manın etik-politik boyutunu tartışmamıza imkân sunar. Alain Resnais'nin Gece ve Sis (Night and Fog, 1955) filmi, travma çalışmalarıyla film çalışmalarının kesiştiği yerde konumlanır. Auschwitz ve Birkenau toplama kamplarının siyah-beyaz arşiv görüntüleriyle günümüze dair renkli görüntülerin bir arada kullanılmasından oluşan film, soykırıma dair görüntüleri doğrudan kullanması nedeniyle temsil tartışmalarının merkezinde yer alır. Filmin biçimi, anlatının çöktüğü anlardan, sessizliklerden, boşluklardan, geleneksel anlatının başarısız olduğu karşılaşmalardan oluşur. Ancak, Gece ve Sis'in sinema tarihindeki önemini tek başına biçimsel tercihiyle açıklamak yeterli değildir. Bu biçimsel tercihin seyirciyi konumladığı etik pozisyon, Gece ve Sis'in, travmanın temsil edilebilirlilik tartışmalarındaki ayrıcalıklı yerinin en önemli nedenidir. Filmin, biçimi aracılığılla geçmişle kurduğu ilişki, seyircisini perdede gördüklerine karşı sorumluluk almaya çağıran etik bir alan yaratır. Böylece film, "temsilin etiği" tartışmalarının referans noktası olarak sinema tarihindeki yerini alır.

anahtar kelimeler: film çalışmaları, travma çalışmaları, hafıza, temsil, post-travmatik sinema 


\section{Giriş}

1956 ylında Cannes Film Festivalinde otuz iki dakikalık Holokost belgeseli gösterildiğinde skandala neden olur. Belgesel, Alman düşmanlığını kışkırttığı gerekçesiyle Almanlar tarafından protesto edilir; bastırılmış bir tarihle ilgili kamuoyu yaratan film, yoğun protestolar sonucunda festival programından çıkarılır. Festival organizatörleri ise misilleme olarak bir Alman filmini dışarıda bırakır (Hebard 1997: 87). Skandala neden olan belgesel yakın zamanda kaybettiğimiz ${ }^{1}$ (2014) Alain Resnais'nin Gece ve Sis (Night and Fog, 1955) filmidir.

Filmin festivalden sonraki yolculuğu ise Almanya'ya uzanır. Cannes'da başlayan tartışma Almanya'da da devam eder. Andrew Hebard'a göre Alman yurtdışı ofisi, Avrupa ülkelerinin tepkisini görece beklendik bulsa da filmin Almanya'da gördügü tepki şaşırtıcıdır. Festivalden sonra film, Almanya'da büyük şehirlerdeki film kulüplerinde ve festivallerde gösterilmeye başlanır, tartışmaların odağı haline gelir, gazetelerde filmle ilgili çok sayıda yazı yayınlanır. Filmin, hükümetin desteğiyle bütün devlet memurlarına izletilmesi gerektiğine dair öneriler de dahi bulunulur (Hebard 1997: 87). Hebard'a göre ulusal bir skandal olarak yolculuğuna başlayan film, daha sonra Almanya'nın Nazi geçmişine dair tartışmalarının merkezi haline gelir (1997: 88).

Peki bu "skandalın kaynağı nedir"? Hebard'dan ödünç aldığım bu soruya öncelikle kendisinin yanıtını aktaralım. Hebard'a göre skandal görüntülerden kaynaklanmıyor, görüntülerin montaj ve anlatı aracılığıyla oluşturulma şeklinden kaynaklanıyor. Bir başka deyişle skandalın kaynağı "filmin kendisidir, filmin temsil biçimidir" (1997:88). Hebard, Cannes'daki skandalın, suç ile sorumluluk arasındaki ayrımları düşünmek bakımından Almanlardaki suçluluğun yeniden değerlendirilmesine yol açtığını ifade eder (1997:111). Filmin biçimiyle seyirciyi bu suç ve sorumluluk alanına nasıl çağırdığı, sinema perdesinde geçmişi hatırla(t)manın, estetik ve etik-politik bir alanda nasıl konumlandığı bu çalışmanın cevaplamaya çalıştığı sorulardır.

\section{İmgeler Yoluyla Hatırlama}

Gece ve Sis filmi travma çalışmalarıyla² film çalışmalarının kesiştiği yerde

1 "Sinema Belleğini Kaybetti", Radikal. http://www.radikal.com.tr/hayat/sinema_bellegini_ kaybetti-1179146, Erişim tarihi: 10.01.2014

2 Holokost ve benzeri felaketlerden (dünya savaşları, etnik savaşlar, modernizmin travması) kurtulmuş kişilerle yapılan çalışmaların yanı sıra bu tür çalışmalardan yola çıkan travma çalışmaları, edebiyat ve film çalışmalarına kaynak olan teorik ve metodolojik yenilikler içerir (Radstone 2001: 10-11). Temel olarak dünya savaşları, Holokost gibi felaketlerle ilişkili olarak ortaya çıkmış olsa da daha geniş bir çerçevede modernizmin kendisiyle ilişkilendirilir (Kaplan ve Wang 2004: 3). Freud, insanın ben-sevgisini ve akılcı bilgisini zorlamış üç yıkıcı travmadan söz eder (Kaplan ve Wang 2004: 3): Illk travma, dünyanın keşfi, başka bir deyişle insanlığın yurdu olan yeryüzünün kozmik evrende küçücük bir parça olduğunun keşfi olarak açıklanabilir. İkinci travma, Darwin'in kuramı, sonuncu ise psikanalizin keşfi ile egonun kendi geçmişinin kaptanı olmadığının açığa 
konumlanır. Bu konumu sinema ile Holokost'un karşılaşması olarak tarif edebiliriz Holokost ve benzeri travmaları temsil etme üzerine düşünmenin bir diğer deyişle travmayı sinema diline tercüme etmeye çalışmanın karşı karşıya kaldığı soru(n) ların peşinden gitmek sinema perdesinde geçmişi hatırla(t)manın etik-politik boyutunu tartışmamıza imkân sunacaktır. Ayrıca bu tartışmaların izini sürmek, Gece ve Sis'in sinema tarihindeki öneminin tek başına biçimsel tercihiyle ilgili olmadığını, bu biçimsel tercihin geçmişle kurduğumuz ilişkiye dair bize ne söylediğiyle, bizi konumladığı etik pozisyonla ilgili olduğunu da açığa çıkaracaktır.

Sinema ile Holokost'un karşılaşmasına verilen ilk yanıt Holokost gibi büyük ve yıkıcı bir travmayı temsil etmenin mümkün olmadığıdır. Yarı teolojik bir yasaklama da içeren bu tartışmaların ${ }^{3}$ travma çalışmalarında temel dayanağı "büyük travmaların bütün temsilleri olanaksız kıldığı" tespitidir (Kaplan ve Wang 2004:4). Cathy Caruth, "temsilin olanaksızlığı"nı, travmatik bir olayın kayıtlara geçmesinin ve anlaşılmasının tam anlamıyla mümkün olmadığı bir karşılaşma anı olmasıyla açıklar (1996:11). ${ }^{4}$ Caruth, bu nedenle travmatik deneyimi, temsil edilemeyen, anlatıya dönüştürülemeyen, tanığı olmayan bir deneyim olarak düşünmeyi önerir (1995:7). Caruth'a göre travmanın, diğer bir deyişle bütünüyle temsil edilmesi mümkün olmayanın izlerini takip etmek, yeni bir tür dinleme ve tanık olma deneyimi yaratabilir (1995:10).

Bhaskar Sarkar'a göre de böylesine belirsiz bir karşılaşmayı değerlendirmek için mevcut hiçbir uygun gösteren (kelime ya da görüntü) yoktur: "Bu çıkmaz, bilgi ve temsil krizi yaratır" (2009:22). Sarkar, travmatik deneyimi anlamada, onu mantıklı bir açıklamanın içine yerleştirmede yaşanan zorluğun, bu deneyimi anlaşılmaz kıldığını, yanlızca belirsiz semptomların varlığını sürdürdüğünü ifade eder (2009: 22). T. Adorno'nun "Auschwitz sonrası şiir yazmak barbarlıktır" cümlesi etrafında kümelenen tartışmalar da büyük travmaların anlatıları, estetik ve temsil pratiklerini gayri meşru kıldığı varsayımına dayanır (Saxton

çıkarılmasıdır. Kaplan ve Wang'a göre bu travmalar, modernlik deneyimi boyunca yaşanan "mutlak olanın kaybıyla" ilişkilidir (2004: 3).

3 Bu tartışmaları derleyen bir çalışma için bakınız: Saul Friedlander (1992), Probing the Limits of Representation, USA, Harvard University Press.

4 Caruth'a göre bunun nedeni bilincin ve belleğin olağan işleyişinin geçici olarak zarar görmesidir (1995: 153-154). Caruth bu tespitini Van der Kolk ve Van der Hart'ın çalışmalarına dayandıırı. Van der Kolk ve Van der Hart'ın çalışmaları, travma sürecinde beyin mekanizmasının kendini ayrıştırdığını göstermiştir (Kaplan ve Wang 2004:5). Bir tür özel hafıza biçimi olan travma nosyonlarında, travma yalnızca anlamı etkilemez, aynı zamanda duygu üretir (terör, korku, şok gibi olağan durumların bozulduğu deneyimlerde oluşan duygular). Başka bir deyişle, travma boyunca beynin duygu bölümü aktiftir, anlam oluşturma yeteneği kapalıdır. Çünkü, etki beyinde kavramsal olarak kayıt edilebilmek için fazladır. Deneyime anlam verilemediği için özne, rüyalarda geri dönüşlerde ve halüsinasyonlarda yakalanır. Van der Kolk ve Van Der Hort'ın ortaya attığı bu teoriye göre travma belleği zayıflatır. Travmatik deneyim bedene işler, çünkü zihne işlenmeyecek kadar yoğundur. Bu anlamda bastırma, deneyimin bilişsel olarak işlenmesi ve sonra unutulmasıdır. Bu nedenle travma bedensel belleğin bir formu olarak görünür. Hafıza bilinçte bir yer bulmaya çalışır, ancak bu çaba halüsinasyon, geri dönüşler gibi travmatik semptomların bedene sızmasıyla sonuçlanır ( akt.Kaplan ve Wang 2004: 5). 
2008: 7). Bu varsayıma göre "Auschwitz açıklanamaz ve görselleştirilemez" olarak ifade edilir ve Holokost'u temsil etmeye yönelik her tür temsil çabasının şüpheli olacağı iddia edilir (Saxton 2008: 7). Ancak bu tartışmalar, Adorno'nun yanlış anlaşıldığı iddiasıyla, temsilin imkansızığından başka türlü temsil etme zorunluluğuna doğru evrilecektir. Örneğin, Shoshana Felman, Adorno'nun daha sonra söz konusu iddiasını yeniden ele aldığını ve şiirin yazılmaması gerektiğini ima etmediğini, daha geniş anlamda sanatın, bu imkansızlığın farkında olarak icra edilmesi gerektiğini dile getirdiğini savunur (1992:34). Bir başka deyişle geleneksel yollarla söz konusu toplumsal kırılmaları ifade etmenin mümkün olmadığı dile getirilir. ${ }^{5}$ Holokostun temsil edilemez oluşuna dair yaklaşıma karşı çıkan LaCapra da Holokostun temsilini, yasaklar ve tabulardan ziyade engeller ve zorluklar bağlamında tartışmayı önerir (1998). LaCapra'ya göre Holokostun temsil edilme tartışması daha genel anlamda Holokostun adlandırılması aynı zamanda etik-politik bir meseledir (1998:16). Böylece sinema ile travmatik bir geçmişin (Holokost) karşılaşmasından doğan tartışmalar, Holokostun "temsil edilemez" olduğuna dair yaklaşımlar ile başka türlü temsil etme gerekliliğini savunan yaklaşımlar arasında bölünür.

Travmatik bir geçmişin film metninde nasıl yer alacağı, travma çalışmalarıyla film çalışmaları arasındaki diyalogu başlatan sorudur. Bu diyalogun kesişme noktasını John Berger'in sorusuyla ifade etmek mümkündür: "Yaralar sese nasıl dönüşür?" (1997:577). Thomas Elsaesser, bu nedenle travma teorisinin, ulusal/ etnik travmaları, sosyal yapıdaki yaraları konu alan film metinleriyle uğraşan akademisyenler için kritik önem taşıdığının altını çizer:

5 Hebard'a göre Holokost, esas olarak tarih araştırmaları alanında merkezi bir tartışmadır. Geleneksel tarih araştırmaları, tarihçinin objektifliğine dayanarak geçmişe bir mesafeden yaklaşıldığı tezine dayanır. Hebard, söz konusu eleştirel mesafenin, tarihsel bilgiyle ilgili kapanmaya neden olduğunu ifade eder. "Ancak Holokost büyük bir travma olduğu ve etkisi devam ettiği için böyle bir kapanmaya izin vermez" (Hebard 1997: 88). Holokost'u temsil etmenin imkansızılılar bağlamında değil, temsilin önündeki engeller bağlamında düşünmemiz gerektiği önerisinde bulunan Dominick LaCapra ise, travmatik bir deneyimin hatırlanmasında iki biçimden söz eder: Dışa vurma (acting-out) ve çözüm işlemi (working-through) (Goldberg 1998: 2). Dışa vurma, travmatik deneyim yaşamış kişilerde görülen zorlayıcı tekrarlardır. Halüsinasyonlar, geriye dönüşler, kabuslar ve tekrar eden kelimeler örnek olarak verilebilir. Bu süreçte kişi geçmişte yaşar, bugünle geçmiş arasında bir sınır yoktur (1998: 2). Çözüm işlemi ise, bastırılanın dile getirilmesidir. LaCapra'ya göre çözüm işlemi sürecinde eleştirel bir mesafe alınmaya çalışıır ve bu mesafe kişinin sorumluluk üstlenmesine olanak sağlar. Ancak bu mesafe, geçmişe tamamen üstün olduğumuz anlamına da gelmez (Goldberg 1998:5). LaCapra, Freud ve psikanalizden aldığı bu kavramları geliştirerek tarih çalışmalarına uygular ve Holokostla ilgili tarihçilerde iki uç eğilimden söz eder (1998:3). İlk eğilim, tarihçinin kendisini görgü tanığı olarak tanımladığı konumdur. Bu konum aşırı özdeşleşme riski taşıyabilir. Tamamen/bütünüyle özdeşleşme olarak tanımladığı bu konumu, ötekinin deneyimini tecrübe etmeye çalışmak ya da farkında olmadan kendini onu yaşarken bulmak olarak açıklar (1998:4). Diğer eğilim ise saf/lekesiz özdeşleşmedir. Bütünüyle inkar olarak tanımladığı bu konum ise aktarımı reddetme, araştırmayı etkileyen etkileri bloke etme ve olabildiğince nesnel ve objektif olmayı ifade eder. LaCapra empati (bütünüyle özdeşleşme) ve eleştirel uzaklık arasındaki hassas ilişkiyi çözmenin geçmişle kurulan ilişkide bir alternatif sunabileceği üzerinde durur (Goldberg 1998: 5). 


\section{Akademik olarak daha saygı gören şekliyle travma teorisi, göndergeselliğin}

içinde bulunduğu krizin, teorik ve politik temellerini yeniden tanımlamaya çalışır. $\mathrm{Bu}$, aynı zamanda hareket eden görüntünün içinde bulunduğu krize de atıfta bulunur. Bu nedenle, travma teorisi, film çalışmalarında yoğunlaşan, özellikle askeri, soykırımsal, ulusal/etnik travmatik olayları konu alan film metinleriyle uğraşan akademisyenler açısından teorik ve pratik olarak önem taşır (Elsaesser 2001: 194-195).

Temsil krizinin bir yönünü Holokost gibi travmatik bir geçmişin nasıl temsil edileceği sorunsalı oluştururken, bir başka yönünü ise imgeye/görüntüye duyulan güven kaybı oluşturur. Söz konusu güven kaybını Alman sinemasıyla tartışan Sarkar'a göre Batı estetik geleneğinde, özellikle de I.Dünya Savaş'ından itibaren yaşanan krizin kendisini açıklamak için bilinçli bir modernist tepki ortaya çıktı. Sinema tarihinde Alman sineması, kolektif travmayla baş etmek zorunda olan ve bu travmaya refleksif bir şekilde yanıt veren en dikkat çekici sinema geleneği olmuştur (Sarkar 2009: 22). Sarkar, temsile duyulan güvensizliğin Alman film endüstrisinin faşist ideolojinin estetik yoluyla yayılmasında gösterdiği suç ortaklığıyla ilişkili olduğunu belirtir ve bu suç ortaklığının film görüntülerini şüpheli hale getirdiğini vurgular: "Yeni temsil stratejileri geliştirilmesi yönünde etik ve politik bir intiyaç vardı. Hayal edilemez olanın görsel temsiline karşı yarı-teolojik yasaklamayla birlikte görüntülere yönelik bu güven kaybı, Holokost'un doğrudan ve gerçekçi sinemasal temsillerine karşı güçlü bir tabu meydana getirdi" (2009: 22). Sarkar'ın sözleriyle ifade edersek, "hayal edilemez olan -tasvir etmeyi bir kenara bırakırsak- nasıl anlatıır?" (2009: 22).

İmgenin güvenirliliğine dair tartışmaların, 20. yüzyılda dönemin travmatik tarihsel olayların temsiliyle yön değiştirdiğini belirten Guerin ve Hallas, temsil, hafıza ve belge tartışmalarıyla Nazi soykırımının temsili üzerine tartışmaların birlikte düşünülmesi gerektiğinin altını çizer (2007: 7). İmgenin hem şüphe kaynağı hem de hakikatin temsili olmasını Nazi kampı görüntüleri üzerinden tartışmayı öneren Guerin ve Roger, tartışmayı 1945 yılında Müttefik kuvvetlerinin kameraman ve fotoğrafçıları tarafından çekilen Nazi kampı görüntüleri üzerinden sürdürür. İskelet gibi çevrede dolanan kamp kurbanlarının filme alınmasının, insan öznesinin bütünlüğüne dair bir saldırı ve tecavüzle sonuçlandığı şeklinde eleştirildiğini belirten Guerin ve Roger (2007:6), bu görüntülerin kampın kurbanlarının bedenlerindeki yıkıcı fiziksel sonuçlarını gösterebilse bile, tutsakların nasıl aşağılandığına dair varoluşsal ve metafizik gerçekliğe asla yaklaşamayacağının ortaya atıldı̆ını ekler: "Bir başka deyişle imge, iddia ettiği şey için hep yetersiz, hep güdüktür" (2007: 2-3). Bir anlamda imgenin yarattığı hayal kırıklığını ele veren bu tartışmaların ve bu imgelere yönelik eleştirilerin, imgenin güvenirliliğini ve güvenilmezliğini aynı anda ele vermesiyle ilişkili olduğunu iddia edebiliriz. Guerin ve Roger, imgeye yönelik bu eleştirilerle birlikte, aynı imgelerin Nazi vahşetinin ve kamp gerçekliğinin belgesi olarak da dolaşıma sokulduğuna dikkat çeker. Ancak fotoğraflar, Almanların kampı terk ettiği, tutsakların özgür bırakıldığı zaman çekilen fotoğraflar olmalarına rağmen, tutsaklık döneminin korkunç görüntüleri olarak 
sunulurlar (2007:3). İmgelerin gerçekliği manipüle ettiğine dikkatimizi çeken bu örnek imgenin içine düştüğü krizi de tanımlamamıza imkan verir: Temsil etme iddiası içinde olduğu gerçeklik karşısında hep yetersiz olan imge aynı zamanda gerçekliği manipüle etme riskini de taşımaktadır. Kuşkusuz bu tespiti sinemanın Holokost'la karşılaşmasının ilk elden sonuçları olarak değerlendirmek mümkün. Bir başka deyişle Holokost'u temsil etme üzerine düşünürken sinema, kendi sınırlılığıyla yüzleşmiştir.

\section{Travmatik İmgeler}

Soykırım ile sinemanın ilk karşılaşması 1941 yııında Reinhard Wiener tarafından çekilen görüntülerle gerçekleşir (Saxton 2008; Hirsch, 2004). Donanmada görevli olan Wiener, çevrede çekim yapmak için izin alır ve askerlerin "orada Yahudileri öldürüyorlar, oradan uzak dur" dedikleri mekana giderek çekim yapmaya karar verir (Hirsch, 2004:1). Daha sonra hendeğe yürüyen ve kurşuna dizilen Yahudilerin iki dakika süren görüntülerini kaydeder. Wiener, görüntüleri arkadaşlarına izlettiğinde onların adeta şoka girdiklerini, sessiz kalıp tepki veremediklerini, kendisinin kayıt yaparken hissettiklerine benzer şekilde sarsıldıklarını anlatır (Hirsch 2004: 2). Hirsch'e göre Wiener yalnızca dehşete tanık olmamış, onu dehşete düşürenin de ne olduğunu kayda almıştır. Böylece seyirci için tanıklık durumu yaratmıştır. Bu nedenleWiener'in filmi şokuaktararak travmatik etki görevini görür: "Film -kurbanlar tarafından büyük ihtimalle ölümden önce sadece bir an olarak deneyimlenen- bir şoku özgül bir mağduriyet sahnesinden diğer sahnelere taşıyan bir travmatik aktarım olarak işlev görür" (2004: 13-14). Bu örnekten yola çıkarak Hirsch, travma-sinema ilişkisini post-travmatik sinema kavramıyla tartışır. Wiener'in hikâyesinin ve filminin, tarihsel travmanın aktarımı ve post-travmatik sinemanın biçimiyle ilgili sinema teorisinin gelişmesinde öncü olduğunu ifade eder (2004: 3). Post-travmatik sinemanın gelişmesinde öncü olan filmler arasında saydığı Gece ve Sis, Shoah (C. Lanzman, 1985), The Pawnbroker (Sidney Lumet, 1965) filmleri üzerinde durur (2004:3). Erken dönem modernist filmlerde, özellikle Fransız deneysel film hareketinde, post-travmatik anlatı özelliklerinin bulunduğunun altını çizer 6 . Hirsch, postravmatik sinemanın ortaya çıkışında Holokost'un önemli bir etkisinin olduğunu belirtir ancak tek faktör olmadığının da altını çizer. Genel anlamda modern sanatı, Benjamin'den alıntı

6 Örneğin Menilmontant (Dimitri Kirsanoff, 1925) filmde parçalı anlatı kullanılarak ana karakterin ailesinin katilini bulması anlatıır (Hirsch 2004: 23). Modern sinemanın ortaya çıkışında Holokost'un nasıl bir etkiye sahip olduğu önemli bir tartışmadır. Nathelie Nazick toplama kamplarını "sinema tarihindeki büyük bir kör nokta" olarak tanımlarken (akt. Saxton 2008:4). J. L. Godard sinemanın kampları temsil etme görevinde başarısız olduğunu öne sürer (akt. Heywood 2009). Ancak, sinemanın kamp gerçekliğini imgeye dönüştürme çabasının sinemanın gelişmesinde önemli ve kurucu bir etkisi olduğu da dile getirilir. Örneğin Saxton'a göre Antonie Beacque bu önemli etkiyi bir adım daha ileri götürerek modern sinemayı kuranın bizzat bu görüntüler olduğunu ileri sürer: "Modern sinema, sonrasında başka biçimlerde yeniden yüzeye çıkan ve daimi olarak sinemada yer alan kameraya bakış, donuk kare, kurmacadaki belgesel özellikler, flashback, montaj, durağanlık ve contemplation gibi kampların varlığına tanıklık eden bu görüntülerden/ sinematografik unsurlardan doğmuştur" (akt. Saxton 2008 :4). 
yaparak endüstrileşme ve kapitalizmle karakterize edilen, modern kapitalizmin travmasına (postravmatik) bir yanıt olarak tarif edebileceğimizi belirtir (2004: 24). Post-travmatik sinemayı, "belirli bir dizi gönderge (Auschwitz, Hiroşima vb.), gösteren (anlatı/öyküleme teknikleri) ve belirli bir gösterilen (travma) arasındaki ilişkiler" olarak tanımlar ve bu nedenle post-travmatik sinemanın müphem, tanımlanmış bir tepkiden ziyade, bir söylem oluşturduğunu ifade eder (Hirsch 2004: 24).

Bir filmi post-travmatik yapan özellikler nelerdir? Bu soruya, filmin gerçeklikle kurduğu ilişki yanıtını vermek mümkündür (Hirsch 2004: 25). Hirsch'e göre bu ilişki, gerçekliği toptan terk etmek anlamına gelmez, daha çok gerçeklikle modernizmin çarpışmasına karşılık gelir. Bu çarpışma, klasik gerçekçiliğin, gerçeğin doğrudan ve bütünüyle temsil edilebilir olduğuna dair iddiası ile modernizmin temsilin her zaman eksik kalacağına dair iddiasının karşılaşmasını ifade eder ve filmlerinin biçimleri de bu gerilimden doğar (2004: 25). Janet Walker'a göre anlatı yapısı doğrusal değil parçalı olan bu filmlerde, senkronize olmayan ses kullanımı yaygındır; ayrıca bu filmlerde tekrarlar, hızlı kurgu ve farklı çekim ölçekleri yer alır. Filmler, geçmişi, olağandışı duygusal efektler, geri dönüşler ve metonomik semboller aracilığıyla sorgularlar ${ }^{7}$ (2001: 214).

Holokostun şiddetinin sinematik imgeleri ve imgelerle olan ilişkimizi köklü biçimde değiştirdiğini ifade eden Saxton, farklı temsil biçimlerinden hareketle tartışmanın yönünü sinemanın "tanık olma sorumluluğuna" ve "temsilin etiğine" çevirir.

Çoğu film yönetmeni, özellikle belgesel türünde film yapanlar arşiv görüntülerini yeniden ortaya koyarken, diğerleri ise bizi bu görüntü yokluğuna tanık olmaktan koruma işlevi gören yeni görüntüler yaratmaktadır. Dahası kimileri, geçmişi görsel bir erişimin restore edilmesinin sinemanın tanık olarak sorumluluğu şeklinde değerlendirirken diğerleri en uygun ve en gerçekçi tanık

7 Güncel örnekler üzerinden travma sinemasının, belgesel film çalışmalarıyla ilişkisinin altını çizen Walker (2001), çağdaş deneysel otobiyografik kadın belgesel pratiklerinin, travma sineması formunun öncüsü olduğunu ifade eder. Feminist ve anti-ırkçı otobiyografik belgesel teorisi ve pratiğinin, son yirmi yıldır kişisel ya da kamusal travmatik olayların temsil sorunu üzerinde durduğunu, daha sonra otobiyografik yazın olarak feminist çalışmalarda bu sorunun tartışılmaya devam ettiğinin altını çizer (2001: 215). Walker bu belgesellere örnek olarak, Daughter Rite (Michelle Citron, 1980), Confessions of a Camelion (Lynn Hershman, 1985), First Person Plural (Lynn Hershman 1990), Familiy Gathering (Lise Yasui, 1988), History and Memory (Rea Tajiri, 1991) ve Talk of Alt (Laura Bialis, Broderick Fox and Sarah Levy, 1999) filmlerini gösterir. Walker'a göre söz konusu belgeseller, standart gazetecilik belgeselciliğine karşı gelerek kamusal/tarihsel konularda yer alan kişisel ve kurmaca özellikleri birleştirerek yeni bir dil arayışına girmişlerdir. "Bu yolla, nesnel belgesel yapım tarzı ile ana akım anlatı arasındaki korelâsyonu ve deneysel belgeselin tarihini anlamadaki potansiyeli hakkında yeni gerçekleri keşfetmişlerdir" (2001: 216). Walker, bu keşfin izlerini History and Memory (Rea Tajiri,1991) belgeselinde arar. Belgesel, I. Dünya Savaşı boyunca Amerika'daki Japon-Amerika kamplarını ele alır. Anlatısını, resmi ve gayri resmi belgeler (kalıntılar, kendi ailesinden fotoğraflar) ile kurmaca öğeleri birleştirerek oluşturur. "Sonuç, karşı-anlatı ve tarih-karşıtı bir anlatıdır". Bu biçimsel tercihin amacı "hakikat"a ulaşmaktır (Walker 2001: 216). 
olma biçimlerinin boşluklar, karanlıklar, sessizlikler ve eksiklikler aracııı̆ıyla dolayısıyla yasaklar ve tabuları yeniden üretmeden gerçekleşebileceğini ima etmektedir (Saxton 2008:15).

Söz konusu biçimsel farklııklar, aynı zamanda sinemanın Holokosta nasıl tanık olacağının da belirlenmesidir. "Tanık olma sorumluluğu" estetiğin etik alanla kesiştiği yerdir. Temsil etmenin etiği tartışmasının, dünyada, özellikle sinemada, Holokost temsil ilişkisi bağlamında gittikçe önem kazandığının altını çizen Saxton'a göre, kampları temsil etmek bir etik sorumluluk meselesidir (2008:15). Serge Daney de benzer şekilde sinemanın belli başlı tarihi olaylar karşısında ayrıcalıklı bir tanık olduğunu ama aynı zamanda bu ayrıcalığının etik bir sorumluluğu olduğunu ifade eder (akt. Saxton 2008:16).

Claude Lanzmann'ın Shoah 8 filmi ile birlikte travmayı temsil etmenin etiği tartışmalarının merkezinde yer alan Geceve Sis, aynı zamanda sinemayla travmanın karşılaşmasından doğan keşiflerin en önemli ve en erken temsilcilerinden biridir. Filmin, toplama kampı döneminin sonrasına dair bir politika ve etik yarattığı dile getirilir (Saxton 2011:88).

\section{Perdede Gördüklerimizden Sorumluyuz: Gece ve Sis}

Yeni bir tarih yazımının sinemasal örneği (Hirsch 2004:44) olarak hatılamanın politikası tartışmalarında referans noktası olan Gece ve Sis, Auschwitz ve Birkenau toplama kamplarının siyah-beyaz arşiv görüntüleriyle günümüze dair renkli görüntülerin bir arada kullanılmasından oluşur. Post-travmatik sinemanın öncüsü olan film, soykıııma dair görüntülere yer vermesi nedeniyle travmanın imgeye dönüştürülmesi tartışmalarının odağında yer alır. Ancak Gece ve Sis'ten önce Holokostun nasıl temsil edildiğini ortaya koymak, Resnais'nin ayırt edici özelliğini tartışabilmemiz açısından önemlidir.

Gece ve Sis filminden önce Holokost iki farklı türde temsil edilmiştir. İlki haber belgesellerdir. İttifak devletleri tarafından çekilen bu belgesellere Hirsch, örnek olarak The Death Camps (1945) filmini gösterir. Toplama kamplarıla ilgili ilk belgesel filmlerden biri olan The Death Camps, yedi tane kampın görüntülerden oluşur; müzik yer almaz (Hirsch 2004: 33). İkinci tür ise derleme filmlerdir. Kamp görüntülerinin Nazilerin suçlarını aktaran bir dış ses ile senkronize kurgulanmasından oluşur. Mein Kampf (Erwin Leiser, 1960) belgeseli de bu türe örnektir. Hirsch'e göre söz konusu belgeseller açık, anlaşılır sorulara objektif, yeterli ve inandırıcı cevaplar verildiğine dair bir öz-güven taşırlar. The Death Camps'ın klasik kurgusu her şeyi bilen her yerde olabilen bir bakış açısı

8 Arşiv görüntülerini doğrudan kullanan Gece ve Sis ile soykırım görüntülerine yer vermeyen Shoah filmi, travmanın temsiline yönelik tartışmalarda iki farklı yaklaşımı temsil ederler. Ayrıntılı bilgi için bakınız: OLIN Margaret (1997), "Lanzmann's Shoah and the Topography of the Holocaust Film", Representations, No. 57, pp.1-23; KOCH Gertrud (1989), "The Aesthetic Transformation of the Image of the Unimaginable: Notes on Claude Lanzmann's 'Shoah' ", October,Vol.48, pp. 15-24. 
varsayar; bir başka deyişle bir güç harcamadan kampta dolaşmak kurbanların pozisyonunu değil kampın dışından bakan otoriter kadir-i mutlak bir bakış açısını varsayar (Hirsch 2004: 34). Bu nedenle The Death Camps, seyircinin bakışını Nazilerin şiddeti ve vahşetine yöneltir; ancak bunun varoluşsal etik ve psikolojik problemlerinden uzaklaşır (Hirsch 2004: 35). Hirsch aynı etik sorunu Mein Kampf'ta da işaret eder. Filmde, seyircinin soykırıma şahit olabilirliğine getirilen herhangi bir sınılama, zamansal bir boşluk veya perspektife getirilmiş blokajlar yoktur: "Seyirci, gaz odalarından başlayarak krematoryumda yakılırken bile izlemeye devam ederek, kurbanlar, soykırıma uğrarken kurbanlara eşlik eden konumuna yerleştirilir" (2004: 39).

Travmatik gerçekliği bütünüyle temsil ettiği iddiasını taşıyan bu filmleri, klasik gerçekçi tarihi filmler olarak kategorileştiren Hirsch, söz konusu anlatının zaman, ses ve bakış arasında hiyerarşik bir ilişki kurduğunu, bu ilişkinin de en nihayetinde seyirciyi, her şeyi bilen, kadir-i mutlak pozisyona yerleştirdiğini savunur (2004: 21). Anlatının doğrusal bir kronolojiden oluştuğunu ${ }^{9}$ ve zaman üzerinde hâkimiyet kurabilmek için zamanın görülebilir, içinde yolculuk edilebilir olduğu yanılgısı yaratıldığını ifade eden Hirsch, böylece geçmişin, bugünün hükmünde görülebilir bir şeye dönüştürüldügünü ekler (2004: 20-21). Bir başka ifadeyle, klasik gerçekçilik, ahlaki/etik olarak tarihin dışında, her şeyi bilen bir bakış açısı varsayar:

Bu kadir-i mutlak kişi görüntüler aracılığıyla tarihe dahil olur; bir başka deyişle bu bakış açısının sahibi, görüntü yoluyla tarihin içine girmekte serbesttir. Söz konusu konum, tarihi dolayımlı bir şekilde görmek ve hissetmek için, bizzat geçmişe bulaşmadan geçmişi bilebileceği ve yargılayabileceği dışsal bir konuma hasarsız bir biçimde, dönme serbestliğine sahip olan çeşitli içe yerleşik bakış açıları varsayar. Klasik gerçekçilik, temsil edilen olaylara dikkat çekerek ve filmin kendi sunum ediminden uzak bir biçimde, geçmişi kendinin bilincinde olmayan bir şey olarak sunar (Hirsch 2004: 21).

9 Hirsch, Aydınlanmayla birlikte doğan tarih yazımındaki klasik doğrusal kronolojinin, tarihçiye belgesel kanıtlar aracılığıyla okuyucuyu geçmişe götürme ve önemli olayların anlatımı aracılığıyla zaman içinde ilerletme olanağı sunduğunu ifade eder. Ancak tarihçinin bu konumunun eleştirildiğini ve bu retoriğin sorgulandığını belirten Hirsch, bu sorgulamaların, tarih yazımının şimdiki zaman bağlamını irdeleyerek klasik tarihsel geçmiş hissini yapı bozuma uğratmaya çalıştığını ekler. Bunun erken bir örneği olarak Nietzsche'nin Tarihin Kullanımı ve Kötüye Kullanımı (1874) (The Use and Abuse of History) adlı eseri olduğunu belirtir ve tarih yazımına yönelik bu eleştirinin ve sorgulamanın, Resnais'de karşılığını ortaya koymaya çalışır: "Resnais'e çok yakın dönemde yaşayan Fransız tarihçi Maurice Blanchot, 1944'te 'tarihçi, geçmişi şimdiki zaman dolayımıyla anlamalı'dır diye yazar. Sinematik bir metafor kullanarak bu tarihsel projeyi gerçekleştirmek için makarayı (iplik makarası) çözmek gerektiğini belirtmiştir". Hirsch'e göre Gece ve Sis belgesel filmi de bu yeni tarih yazımı anlayışını pratiğe dökme yönündeki ilk büyük çabayı temsil eder (2004: 44). 
Klasik gerçekçi filmlerin bir alt-türü olan geleneksel tarihsel filmler ${ }^{10}$ böylece geçmişi görünür kılarak geçmiş üzerinde hakimiyet kurmaya çalışılar. Bu tür filmlerde seyirci "hiç yara almadan tanık pozisyonuna kayıp düşebilir ve tekrar bu pozisyondan çıkabilir, böylece Holokost'a bir görüntü olarak hükmedebilir" (Hirsch 2004: 21). Seyirciyi, kadir-i mutlak konuma yerleştirerek seyircinin perdede gördüklerine güvenli bir mesafeden dahil olmasına imkan veren anlatının aksine post-travmatik anlatı, seyircinin hayali efendilik konumunu bozguna uğratır. Doğrusal bir kronolojiye dayanan ve seyirciye perdede gördükleri üzerinde mutlak bir hâkimiyet vaat eden klasik gerçekçiliğin kronolojik akışını yapıbozumuna uğratır (Hirsch, 2004: 21-22). Zaman üzerinde hâkimiyet kurulamaz; zaman, parçalı ve kontrol edilemez şekilde deneyimlenir, "davetsiz şekilde bugüne musallat olan ulaşılamayacak geçmiş olarak bilinci ele geçirir" (Hirsch 2004: 21-22). Post-travmatik anlatıyı belirli bir çeşit anlatının çöküşü, bozguna uğraması olarak tanımlayan Hirsch, bunun sonucunda seyircinin kadir-i mutlak bakış açısının ve zaman üzerindeki kontrolünün de bozguna uğradığını ifade eder. Bu nedenle posttravmatik öyküleme, "öykülemenin başarısızlığı- zaman ve bakış üzerindeki hâkimiyet kaybı-olduğu ölçüde bir öz-bilinç sesi geliştirmeye, geçmişe hâkim olmadaki başarısızlığına ilişkin düşünmeye yöneltir" (2004: 23).

Post-travmatik sinemanın en önemli örneklerinden biri olan Gece ve Sis günümüze dair renkli görüntülerle açılır. Hareketli bir kamera ile çitlerin arkasından boş bir alan gösterilir. Kamera çitlerin önünde kaydırmalı çekimle hareket eder ve çitlerden geçerek alana girer. Hareketli kamera görüntüsüne eşlik eden dış ses, bakışımıza sunulan bu "huzurlu" mekanın bir zamanlar mahkumların yakıldığı toplama kampına giden yol olduğunu söyler (şekil 1). Filmin açıış sekansı, şimdiki zamana dair tahayyülümüze gölge düşürür. Sıradan görünen şimdiki zamanda boş bir mekâna Resnais'nin kamerasından baktığımızda, geçmişin dehşetinin mekanı olduğunu öğreniriz. Perspektifimizi büken bir anlamda bu yamuk bakış, Resnais'nin biçiminin işaret ettiği hakikati de özetler: Geçmişin suçları şimdiki zamanda hüküm sürer. Gece ve Sis'in sinema tarihindeki önemi, filmin biçimi aracılığıyla bu hakikatle kurduğu ilişkidir.

10 Bu filmlere arasında Bir Ulus'un Doğuşu (The Birth Of A Nation, David Wark Griffith, 1915) ve Titanic (Titanic, James Cameron, 1997) filmine uzanan geniş bir yelpaze bulunmaktadır (Hirsch 2004: 20). 


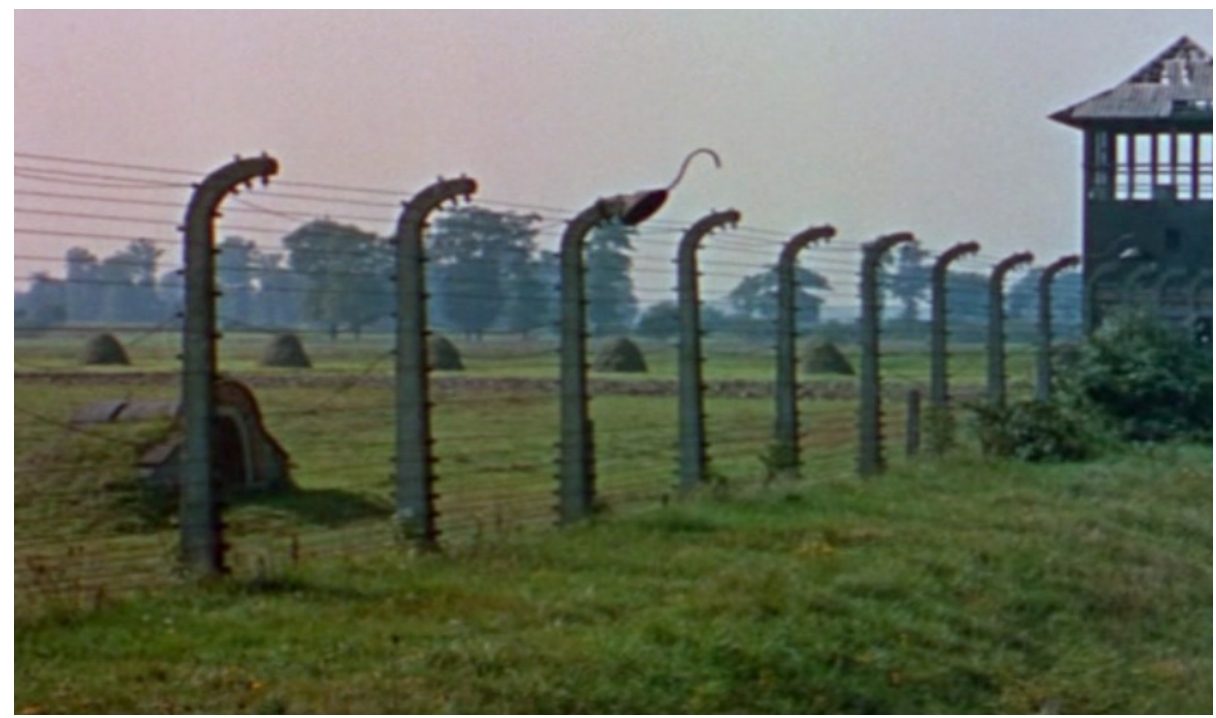

Şekil 1: Sıradan görünen, şimdiki zamanda boş bir mekâna, Resnais'nin kamerasından baktığımızda, geçmişin dehşetiyle yüz yüze geliriz.

Filmin en çok tartışılan biçimsel stratejisi, arşiv görüntüleriyle şimdiki zamana ait görüntülerin bir araya getirilme biçimidir. Filmin açılış sahnesindeki renkli görüntülerin ardından, 1933 yazısı ile arşiv görüntülerine geçilir. Nazi askerlerinin yürüyüşüne kesilerek yapılan bu geçişle birlikte, geçmişle şimdiki zamanın sınırlarının altı oyulmaya başlanır. Resnais, film boyunca şimdiki zaman görüntüleriyle arşiv çekimlerini bir araya getirir, ancak bu yanyanalık, birinden diğerine sorunsuz bir geçişi değil, ikisi arasındaki sınırın muğlaklaştırımasını ifade eder. Bu muğlaklık, en nihayetinde şimdiye musallat olan geçmişin görünür olduğu bir perspektif değişimini mümkün kılar. Resnais, aynı zamanda hareketli görüntülerle sabit çekimleri bir arada kullanarak da geçmiş ile şimdikizaman ayrımını bulanıklaştırır. Resnais'nin kampta gezen kamerası hareketlidir, arşiv çekimleri ise çoğunlukla durağandır. Hebard'a göre sabit ve hareketli bakış açılarındaki salınım, geçmişi ile şimdi arasındaki biçimsel farkı kurar, ancak Resnais daha sonra bu farkı bükerek geçmişle ilişkimizi bulanıklaştırır (1997:95). Bir başka ifadeyle, bu fark, geçmişin travmasının bugünde hüküm sürdüğünü tartışabileceğimiz bir alan açmak için yapı bozuma uğratılır. Şimdiki zaman ile geçmiş zaman arasındaki sınırları muğlaklaştırarak doğrusal zaman akışını parçalayan Resnais, böylece geçmiş üzerinde egemenlik kuran geleneksel anlatılardan ayrılır. Bu zaman anlayışı, Gece ve Sis'i post-travmatik sinema örneği yapan en önemli biçimsel stratejidir. Resnais'nin geçmişle kurduğu ilişkinin nüvesi olan bu tercih, geçmişi bugünden ayıran zaman kavrayışını radikal şekilde dönüştürür: "Bu zaman kavrayışıyla düşünüp durduklarımızdan biri, tarihi nesneyle, geçmişle, geçmişte 
yaşanmış adaletsizliklerle birlikte nasıl yaşayacağımız ise, diğeri onunla birlikte yaşamayı öğrenmek için onunla kuracağımız ilişkinin biçimidir. İlki etik, siyasi adalet, sorumluluk meselesi, ikincisi sinemasal biçim veya estetik tercihtir" (Arslan 2014).

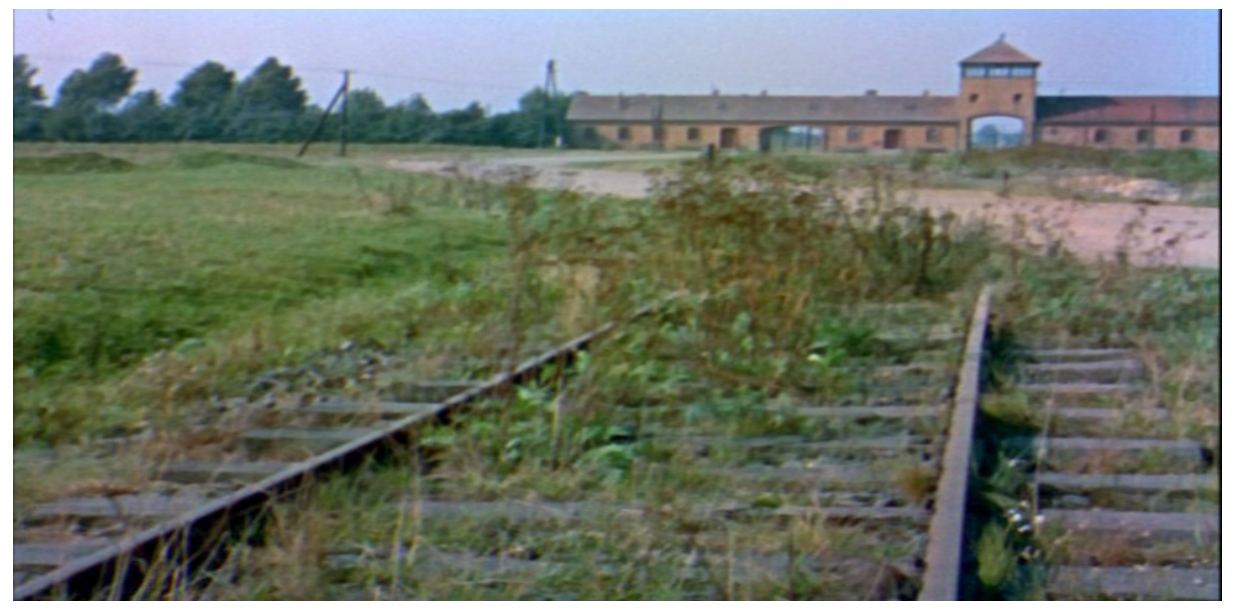

Şekil 2: Resnais, mahkumların kampa götürüldüğü tren raylarının bugünkü görüntüsü üzerine şu soruyu sorar: "(..) Neyi görmeyi umuyoruz?"

Gece ve Sis'in, günümüze ait renkli görüntülerle siyah-beyaz görüntülerin bir arada kullanımı, hareketli görüntülerden sabit arşiv görüntülerine geçişleri, seyirciyi birden çok bakış açısına maruz bırakır. Saxton'a göre perspektifteki bu kaymaların politik işlevi, güvenli bir mesafeden toplama kampına bakmamıza engel olmaktır (2011:147). Resnais'nin estetiği, "geçmişin travmasının bütünüyle temsil edilemeyeceği" hakikatini ifşa eder. Resnais, tren vagonlarında insanların kampa götürülüşüne dair arşiv görüntülerinden, renkli çekimlerle tren rayının bugünkü görüntüsüne keser. Tren rayları üzerinde kamera ilerler ve dış ses bize ne aradığımızı sorar: "Aradığımız nedir? Vagonlardan düşen cesetlerin izleri mi?" (şekil 2) Geçmişin yalnızca izlerin peşinden giderek temsil edilebileceğini iddia eden Caruth'u hatırlatan bu cümle, filmin izlerin peşinden gitme çabasını sorgular. Ancak film, geçmişi temsil etmenin imkânsızlığını her çerçeveleyişinde, anlatısı da kendi amacına dair sürekli bir sorgulamaya dönüşür. Kampın gerçekliğini içinde yaşayanların bile tam olarak bilemediğini söyleyen dış ses, "gerçekliği görmek için nasıl ümit edebilir?" diye sorar. Yönetmeninin, seyirciye "gerçeğin asla tam olarak aktarılamayacağını" itiraf eden bu cümle, aynı zamanda sinemanın sınırlıığını da ifşa eder. Böylece izlerin peşinden gitmek için yola çıkan film, kendi imkânsızlığının metnine dönüşür. 
Resnais, gördüklerimizin gerçeği bütünüyle asla temsil edemeyeceğini, sinemanın (travmatik) gerçek karşısında yetersiz kalacağını filmin metninde sürekli ifşa eder. Klasik tarihi filmlerde aralarında hiyerarşik bir ilişki kurulan ${ }^{11}$ ve birbirlerini destekleyen görüntü ve ses kanalının arasındaki bu ilişki tarihsel travma karşısında yerle bir olur: "Kampların gerçekliği... biz boşuna kalıntılarını keşfetmeye çalışıyoruz. Bu tahtadan yapılmış barakalar, uyudukları raflar... Hiçbir tanım, hiçbir görüntü onların gerçek boyutunu, kesintisiz korkuyu anlatamaz". Burada itiraf edilen, şok ediciliklerine rağmen arşiv görüntülerinin bile kamplarda yaşananları temsil edemeyeceğidir. Film, bu itiraftan sonra dehşeti bütünüyle aktarmanın imkânsızlığına teslim olur: "Bu korkunun size ancak bir kısmını, yüzeysel tarafını gösterebiliriz". Film yaşanan dehşeti aktaramayacağını ve seyircinin hayal gücüne zorunlu olduğunu şu sözlerle ifade eder: "İnsanın içine işleyen çığlıkların atıldığı o geceyi sizin hayal gücünüze bırakıyoruz..." Görüntülerin sınırlıı̆̆ını ifşa eden sözel anlatı da aynı imkânsızlıktan mustariptir. Kampta yakılan cesetlerin, saçların, kemiklerin daha sonra sanayide nasıl kullanıldığını aktaran dış ses, anlatıya devam ederken "cesetler...söyleyecek söz bulamıyorum" diyerek sessizliğe gömülür. Sözel anlatı da, görüntünün travmatik gerçek karşısındaki yetersizliğinin neden olduğu boşluğu dolduramaz, aynı yetersizliğe yenilir. Gece ve Sis'in ses ve görüntü arasında kurduğu bu ilişki, travmatik gerçekliğin bütünüyle temsil edilmesinin mümkün olmadığına dair yaklaşımın biçimsel ifadesidir. Ses ve görüntü kanalının, bir başka deyişle sinemanın araçlarının travmayı temsil etmedeki başarısızlığı ya da yetersizliği, Resnais'nin biçiminin kurucu unsurudur. Resnais'e göre geçmişin baş edilemeyen tarihsel travması, klasik tarih anlatısını geçersiz kılar (Hirsch 2004:42). Geleneksel yollarla travmayı temsil etmeyi reddeden Resnais'nin estetiği, anlatının çöktüğü anlardan, sessizliklerden, boşluklardan, geleneksel anlatının başarısız olduğu karşılaşmalardan oluşur. Böylece Gece ve Sis, travmanın temsil edilebilirlik tartışmasına verilmiş biçimsel (estetik) bir yanıt olarak sinema tarihindeki yerini alır.

11 Gerçekçi tarihi filmler, bu üçü arasında hiyerarşik bir ilişki kurar. "Görüntü izi, seyirciden gördüklerine inanmayı talep eder ve hiyerarşinin en başında yer alır. Baskın konumda yer alması, görsel kanıtın ampirik söylemine başvurulmasından kaynaklanır. Hiyerarşi de ikinci pozisyonda yer alan dış-ses, tarihsel metindeki imgeye yerleşerek ona tarihsel bir anlam verir. Üçüncü sırada ise müzik yer alır. Tarihsel türlerle (epik, trajik, komik) tarihsel anlatıyı birleştirmek için duygusal bir ipucu sağlar" (Hirsch 2004: 42). 


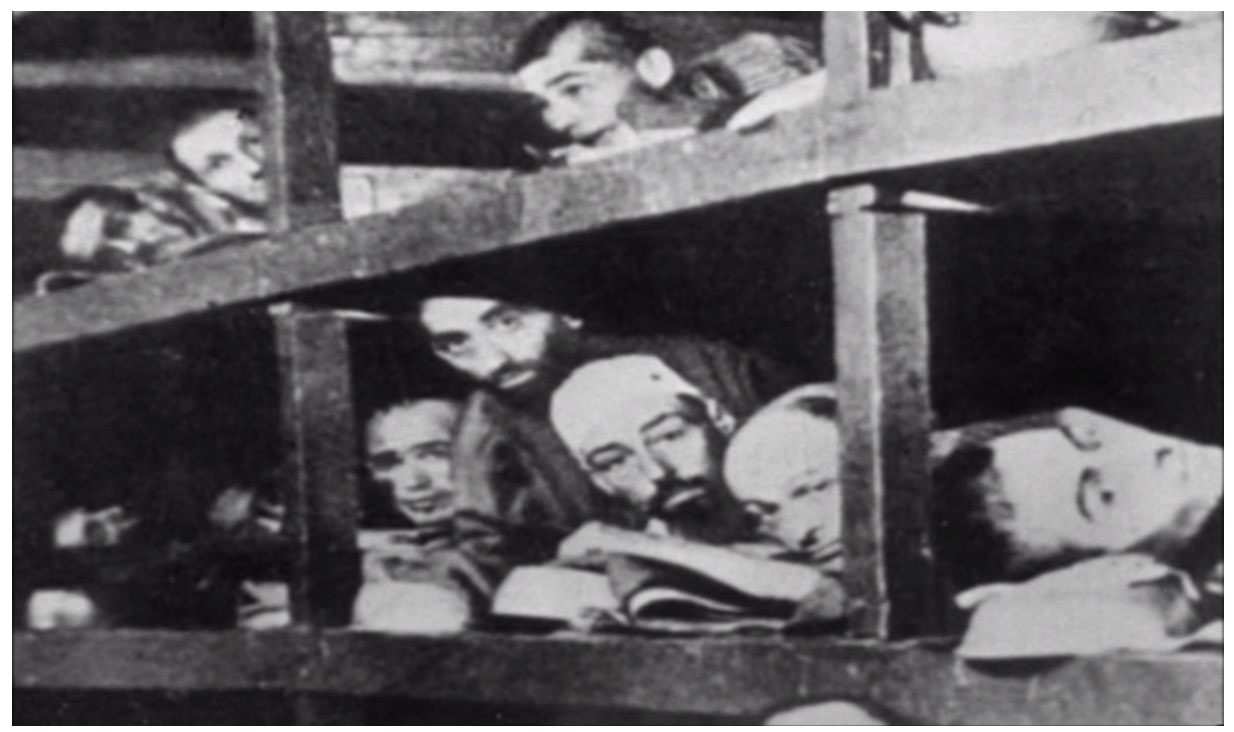

Şekil 3: Gece ve Sis'te bastırılan geçmiş, arşiv görüntüleryle bugüne sızarak şimdiye musallat olur.

Todd McGowan da benzer şekilde, filmin anlatısının, kamplardaki gerçeği bilmenin imkansızlığı üzerinde durduğunu belirtir ancak bir şerh düşer: Resnais, buna rağmen "bu gerçeği arşiv görüntüleriyle tasvir etmeye gayret eder" (2012:295). McGowan'a göre bu paradoks, Resnais'nin tarihle kurduğumuz ilişkiyi algılama biçiminden doğar12: "Resnais kendine ait biçimsel yaklaşımıyla geçmiş ve şimdiyi karşı karşıya getirerek, geçmişi fantezinin merceğinden sunar. Menzilimizin ötesine uzanan bir geçmişle değil, fantazmatik bir formla şimdiki zamanda bulunan bir geçmişle karşılaşırız" (2012: 295). McGowan, Gece ve Sis filminde Nazi bakışının bulaştığı arşiv görüntülerinin, gerçeğin bütünüyle temsil etmenin aracı olarak değil, günümüz görüntülerinde artık bulunmayan bir şeyin (soykırımın) altını çizmek için kullanıldığını ifade eder (2012:296). Travmatik olanı görsel alana dahil etmedeki başarııızlık, "tarihsel nesnede kendi payımıza düşeni kabullenmeye bizi mecbur bırakır" (2011:296). Böylece Resnais, travmatik geçmişin temsil edilemezliğini ifşa eder ancak geçmişi de ulaşılmaz bir konumda bırakmaz. Geçmiş, şimdide, "onu görmezden gelmeye çalıştığımız noktada var olur" (2012:297)

12 Tarihsel nesnenin -ya da bizzat tarihin kendisinin- imkansız bir nesne konumunda olduğunun altını çizen McGowan'a göre (2012:291) tarihe oldukça spesifik bir perspektiften yaklaşırız, söz konusu perspektif, onda neyin sabitlenebileceğini gösterirken, aynı zamanda dışarıda bıraktıklarına karşı bizi körleştirir: "Ayrıca geçmişin kendisiyle kurduğumuz ilişkiyi kaçınılmaz olarak renklendiririz. Geçmiş, tarihe ilişkin yönelimimizden dolayı kendinde var olduğu haliyle değil, bizi bugüne taşıdığı şekliyle görünür Tarihsel gelişimin ilerlemeci anlatımından kaçınsak bile, tarihi şimdinin merceğinden yorumlayan bu perspektifin yanılsamasından kaçamayız" (McGowan 2012: 291). 
O halde Resnais, estetiğiyle bize aynı anda iki şeyi söyler: Geçmişte yaşanan şiddeti tüm gerçekliğiyle, sarsıcılığıyla temsil etmek mümkün değildir (hiçbir görüntü onların gerçek boyutunu, kesintisiz korkuyu anlatamaz). Ancak bu imkansızlık, geçmişin, bütünüyle bugünden uzak, şimdiki zamana sesini ulaştırmayacağı bir uzaklıkta olduğu anlamına da gelmez. Aksine, geçmiş ve bugün arasındaki ayrımı bulanıklaştırmak, arşiv görüntülerini şimdiki zamana sızan bir ses/görüntü olarak kullanmak, geçmişin bugündeki etkisini görünür kılmaktadır. Arslan, hem dolaysızca arşiv görüntülerine yer vermenin hem de geçmişi ulaşımaz boyutta bırakmanın olumsuzlandığı bu keşfin iki evreni iç içe geçirdiğinden söz eder: "Böylelikle tarihsel nesneyle, 'her şeyi gördüm' ayartısına kapılacak bir biçimde değil, imkansız-nesne olarak karşılaşırız. Bakış açımızın bu yetersizliğine maruz kalmak, kendi kırılganlığımızı, gerçekliğimizin kırılganlığını deneyimlediğimiz etik bir konumdur" (Arslan 2014). Filmin etik pozisyonunu, bir kez daha tarif edebileceğimiz bir diğer sahne ise filmin sonlarına doğru Nazi bakışını paylaştığımız sahnedir. Filmin sonunda kamera yıkıntılar arasında gezinirken dış-ses "9 milyon ölünün ruhu bu kırlarda geziniyor" der, harabe bir gözetleme kulesinin görüntüsü üzerine ise, "bu tuhaf gözetleme kulelerinde kimler gözcülük yaptı? Kimler cellatlara emir verdi?" sorularını sorar ve devam eder (gözetleme kulesindekilerin) "yüzleri bizim yüzümüzden sahiden farklı mıydı?". Filmin ortalarında, gözetleme kulesinde askerlerin baktığı yerde konumlanan seyirci, filmin sonlarında "yüzlerimiz onlardan faklı mı" sorusuna muhatap kalacaktır. Resnais, seyircinin perdede gördüklerinden kendini muaf tutamayacağı, failin bakışını paylaşmak zorunda kalacağı bir perspektif inşa ederek seyirciyi etik bir yüzleşmeye mecbur bırakır.

Gece ve Sis'in temsil politikası Resnais'nin bir sonraki filmi Hiroshıma Mon Amour (Hiroşima Sevgilim, 1959) filminde de devam eder. Saxton'a göre hem Hiroşima Sevgilim hem de Resnais'nin bir sonraki filmi Muriel ou Le temps d'un retour (Acı Hatıralar, 1963) Gece ve Sis ile aynı çıkmazdan yola çıkar: "Kendi projelerinin imkansızlığına dair bir öz bilinç" (2008:116). Hiroşima Sevgilim'in senaristi Margeret Duras, film hakkında şunları söyler: "Yapılabilecek tek şey Hiroşima hakkında konuşmanın imkansızlığı hakkında konuşmaktır" (akt. Saxton 2008 :116). Film, hem imkansızlığı (tarihsel travmanın bütünüyle temsilinin) sahneler hem de deneyimlemeye kapı açar. "Her şeyi gördüm" diyen Fransız kadını ile "Sen hiçbir şey görmedin Hiroşima'da, hiç!" cevabını veren Japon erkeğinin hikayesi, şimdide tezahür eden, ama asla temsilde bütünüyle tüketilemeyen geçmişin hayaletinin görünür olduğu bir karşılaşma anıdır. Bu filmlerde de Resnais'nin imgeleri bastırılan, yok sayılan bir geçmişin bugündeki tezahürüne dönüşür, başka bir ifadeyle Resnais'nin evreninde "imkansız nesne, yokluk olarak kendi hakikat payını talep etmektedir" (Arslan, 2014).

\section{Sonuç}

Marx'ın Hayaletleri kitabında Jacques Derrida, siyasal ya da başka türden şiddet uygulamalarının, ulusçu, ırkçı, cinsiyet ayrımcısı ya da daha başkaca 
kıyımların kurbanı olmuş ya da olmamış kişilerin hayaletleri karşısında, herhangi bir sorumluluk almaksızın adaletin mümkün olamayacağından söz eder (2001:12). Derrida'ya göre, misafirperverlik ve adalet imkanı, hayaletleri kovmakla değil onlara haklarını vermekle olanaklıdır (2001:264). Hayaletlerle konuşmayı öğrenerek, sözü onlara bırakarak yaşamayı öğrenmeye çağıran Derrida (266), bir anlamda geleceğin nasıl bir gelecek olacağını belirleyenin, geçmişle kurulan ilişki biçimi olduğunu ifade eder.

Tarih sahnesinde bastırılan bir travmayı ya da kolektif bir suçu imgeye dönüştürürken, onu temsilde tüketmeyen, geçmişin evrenine hapsederek seyirciye güvenli bir pozisyondan suça tanık olmasına ya da suçu inkar etmesine imkan vermeyen Resnais de perdesini geçmişin hayaletlerine bırakır. Gece ve Sis, şimdiki zamanda geçmişin suçlarıyla kurulan ve sorumluluktan azade ilişkiyi ve yaşananların bugün artık var olmadığına duyulan inancı yeniden düşünmeye çağırır. Filmde yer alan şu cümleleri hatırla(t)manın tam yeri burasıdır: "Sanki bütün olan biten yalnızca bir kez, verili bir zaman ve mekanda gerçekleşmiş gibi davranıyoruz; bizi kuşatan şeylere karşı gözlerimiz körleşmiş ve insanlığın bitip tükenmez feryadına karşı kulaklarımız sağırlaşmış durumda".

O halde Gece ve Sis'in evreninde seyircinin payına düşen nedir? Kuşkusuz geçmişin suçları, adaletsizlikleri karşısında bugün alınan pozisyonun etik sorumluluğudur. Cannes'da skandal yaratan da bu etik sorumluluğa dair çağrıdır. "Bütünüyle sorumlu olmayı kabullenmeye zorlayan bu evren" (Arslan, 2014) geçmişin hayaletlerinin görünür olduğu bir yüzleşme perdesidir. Bu nedenle, Resnais'nin perdesinden gelen ses ve görüntüler, sadece geçmişi hatırlatmakla kalmaz, seyirciyi, yok saydıklarının bugünü nasıl kuşattığını görmeye ve geleceğe dair sorumluluk almaya davet eder.

\section{Kaynakça}

ARSLAN U. Tümay (2014), "Sesler, Hayaletler, Melekler", http://www.agos. com.tr/haber.php?seo=sesler-hayaletler-melekler\&haberid=6743, 8.03.2014

BERGER James (1997), "Trauma and Literary Theory", Contemporary Literature, No. 38 (3), pp. 569-582.

CARUTH Cathy (1995), Trauma: Explorations in Memory, USA, The Johns Hopkins University Press.

CARUTH Cathy (1996), Unclaimed Experience, Baltimore and London, The Johns Hopkin University Press.

DERRIDA Jacques (2007), Marx'ın Hayaletleri, İstanbul, Ayrıntı Yayınları.

ELSAESSER Thomas (2001), "Postmodernism as Mourning Works", Screen, No. 42 (2), pp. 193- 201. 
FELMAN Shoshana (1992), Education and Crisis, or the Vicissitudes of Listening, Shoashana Felman\& Dori Laub (Ed.), Testimony: Crises of Witnessing in Literature, Psychoanalysis and History (1-57), New York, Routledge.

GUERIN Frances ve R. Hallas (2007), Introduction, Frances Guerin ve R. Hallas (Ed.), The Image and The Witness (1-20). London, Wallflower Press.

HEBARD Andrew (1997), “Distruptive Histories: Toward a Radical Politics of Remembrance in Alain Resnais's Night And Fog", New German Critique, No.71, pp. 87-113.

HEYWOOD Miriam (2009), "Holocaust and Image: Debates surrounding JeanLuc Godard's Histoire(s) du cinéma", Studies in French Cinema, No.9 (3), pp. 1988-98.

HIRSCH Joshua (2004), After Image: Film, Trauma and Holocaust, USA, Temple University.

KAPLAN E. Ann (2001), "Melodrama, Cinema and Trauma”, Screen, No.42 (2), p.201-205.

KAPLAN E. Ann ve B. Wang (2004), "Introduction: From Traumatic Paralysis to the Force Fiedld of Modernity", E. Ann Kaplan, B. Wang (Ed.), Trauma and Cinema (p. 1-23). Hong Kong, Hong Kong University Press.

GOLDBERG Amos (June, 1998), "An Interview with Professor Dominick LaCapra", http://www.yadvashem.org/odot_pdf/Microsoft\%20Word\%20-\%20 3648.pdf, 10.01.2014

MCGOWAN Todd (2012), Gerçek Bakış, Zeynep Özen Barkot, Çev. İstanbul, Say Yayınları.

RADSTONE Susannah (2007), Trauma Theory, Context, Politics, Ethics, Paragraph, Vol. 30 (1), pp. 9-29.

SARKAR Bhaskar (2009), Mourning the Nation: Indian Cinema in the Wake of Partition, England, Duke University Press.

SAXTON Libby (2008), Haunted Images, London, Walflower.

SAXTON Libby (2011), "Night and Fog and Concentrationary Gaze", Griselda Pllock and Max Silverman (Ed.), Concentrationary Cinema (140-152). New York, Berghahn Books.

SILVERMAN Max (2011), "Fearful Imagination: Night and Fog and Concentrationary Memory", Griselda Pllock and Max Silverman (Ed.), Concentrationary Cinema (199-214). New York, Berghahn Books.

WALKER Janet (2001), "Trauma Cinema: False Memories and True Experience",

Screen, No:42 (2), pp. 211-216.

WILSON Emma (2005), “Materials Remains: Night and Fog”, October, No. 112, pp. 89-110.

YOSEF Raz (2011), The Politics of Loss and Trauma in Contemporary Israeli

Cinema, London, Routledge. 